\title{
Investigating the Implementation of Constructivist Teaching Techniques, Challenges and Opportunities of an English Foreign Language Teacher in Beseka Secondary School, Grade Nine Writing Class in Focus
}

\author{
Kalicha Guyo Galgalo ${ }^{1 *}$, Abdi Aden Yasin ${ }^{2}$, Zubeyda Abdella Tuna ${ }^{3}$, David Ali Shoko ${ }^{4}$, Galgalo Aga ${ }^{5}$ \\ ${ }^{1}$ Beseka Secondary School Principal, Akaki Kality sub city, Addis Ababa \\ ${ }^{2}$ Lecturers at Department of Public Administration and Development Management, Wolaita Sodo University, Wolaita, Ethiopia \\ ${ }^{3}$ Akaki Birhu Tesfa Primary School, Akaki Kality sub city, Addis Ababa \\ ${ }^{4}$ Save the Children Ethiopia, Ware House Officer, Hawassa Southern Ethiopia \\ ${ }^{5}$ Moyale Woreda Government Communication Bureaus, Moyale Borena Zone
}

\begin{tabular}{ll}
\hline DOI: $\frac{10.36348 / \text { jaep.2020.v04i03.001 }}{\text { *Corresponding author: Kalicha Guyo Galgalo }}$ & | Received: 28.12 .2019 | Accepted: 04.01.2020 | Published: 21.03 .2020
\end{tabular}

\section{Abstract}

This research investigating the implementation of constructivist teaching techniques, challenges and opportunities of an English foreign language teacher in Beseka Secondary School, grade nine writing class in focus. The nature of the study can be descriptive study. The population of this study consisted the entire English foreign language teacher and grade nine student in regular programmes in all the tertiary institutions in Akaki Kality Sub city in Addis Ababa in the $2016 / 2017$ academic session, which were 720 in number. The sample size for the study was 84 , which is $10 \%$ of the entire population. The major research tool used to gather data was observation. The second tool is semi structured interviews for teachers. The third one was questionnaires administered to teachers and students who were selected randomly from grade nine students. After the data had been collected the responses to the questionnaire part and information obtained through observation and recordings were counted and tallied then, descriptive statistics were employed in analyzing the quantitative data while content analysis was applied in analyzing the qualitative data. The collected raw data was analyzed using mean score for quantitative method of data analysis and qualitatively interpretation to ensure the reliability and validity of the collected data. Findings revealed the challenges and opportunities of an English foreign language teacher in Beseka secondary school, grade nine writing class face and also indicated that these challenges negatively affect the academic performance of these students. Based on the findings, some recommendations were made which includes that students must have the behavior of cooperating, helping one another to draft or revise what they write and so on. Rather than total dependency on those whom they think are better than them. Also, teacher should show concern by informing students how and when assessments will be and make study materials/resources readily available so as to enable students prepare adequately for improved academic performance.

Keywords: Implementation, constructivist teaching, challenges, opportunities.

Copyright @ 2020: This is an open-access article distributed under the terms of the Creative Commons Attribution license which permits unrestricted use, distribution, and reproduction in any medium for non-commercial use (NonCommercial, or CC-BY-NC) provided the original author and sources are credited.

\section{INTRODUCTION}

In recent years, one of the prominent changes observed in general education including the area of language teaching is the change in the understanding that knowledge is something that is constructed by a learner rather than received [1]. This change, which has been introduced by the theory of constructivism, has predominantly changed the role of language teachers from providers of knowledge to creators of a situation where knowledge creation by language learners is possible [2]. In this regard, teachers are recognized as active generators of contextualized knowledge necessary to be effective in their teaching practice.
According to Wallace [3], requires language teachers to continuously revise their prior knowledge gained from earlier exposures in a way that fits current classroom realities. They do this through an active enquiry into and reflection on their practices and whatever is involved in the whole process. This engagement of language teachers in the task of enquiry and investigations is expected to enable them to construct knowledge that is necessary to help language learners of diverse needs and styles $[4,5]$. 
Moreover, English language has four basic skills of listening, speaking, reading and writing. These four basic skills are interconnected and are all relevant to the English language proficiency and aid effective communication. Effective communication entails following instructions after reading what has been written, conversing, giving and receiving feedbacks which involve speaking and listening skills. Hence Perin [6] stated that learning the four basic skills can be a satisfying and mind-expanding activity to those who have acquired them; but a frustrating and even aversive experience when the skills are lacking. For most people however, writing skill is often viewed as the most difficult of the skills.

Generally this study was conducted on grade Nine EFL teachers' perception and practice towards constructivist approach and challenges that affect them during implementing this approach in writing classroom at Beseka secondary school which is one of government school found in Akaki Kality sub city.

\section{STATEMENT OF THE PROBLEM}

However, in native language environments, productive skills develop differently. Writing, unlike speaking, involves a process of formal learning, while speaking develops naturally through a process called "acquisition" [7] whereas writing undertake a process of formal learning, most native speakers never master this skill [8]. In the same line, Nunan also affirms that when facing writing the "challenges for second language learners are enormous". In addition, the researcher's viewpoint based on his own experience is that in foreign language teaching settings, the challenges for students to develop writing skills are even the most demanding issues that each and every teacher should play a fundamental to enhance the students' levels of achievement.

According to Alamirew G/Mariam [9], Yonas Adaye's [10] research reveals similar problems in the area of teaching writing skills and they argued that students writing performance is low because writing is not effectively taught in high schools. Also Geremew Lemu [11], in his doctoral dissertation, found out that students' writing in different faculties of AAU is weak in treating a given topic both in content and form. He noted that students were unable to identify the relevant information from the irrelevant one and had lack of organizing skills of connected discourse in composition.

On the other hand, there is no research done currently in this area i.e. in Beseka Secondary School, from his own teaching experience and from what other colleagues consider to be true in the other schools, the researcher believes that there exist inadequate students' writing skills especially in organizing, sorting out the difference between topic sentence and supporting details, hesitate to write freely on any topic without the teachers' involvement as the process of discovering and making meaning.

\section{OBJECTIVE OF THE STUDY General Objective}

The general objective of this study is to investigate the implementation of constructivist approach in case of Beseka Secondary, grade nine EFL Teachers.

\section{Specific Objectives}

The specific objectives are the following:-

1. To investigate an extent to which constructivist approach is carried out at Beseka secondary school particularly by grade nine EFL teachers

2. To assess teachers' perception toward constructivist approach

\section{Research Question}

1. To what extent an EFL teacher's practice constructivist approach in writing classroom?

2. What are teachers' perceptions towards constructivist approach while teaching writing?

\section{METHODS}

The nature of the study can be descriptive analysis. Though more descriptive analysis suits the study, the researcher has also used the qualitative method particularly to analyze the interview, observation through thematic and content analysis method are used. The data collected through questionnaire is tabulated and described qualitatively.

The study was conducted at Beseka secondary school, particularly grade nine EFL teachers, it is found in Akaki kality sub city, located at southern part of the capital city of Ethiopia, Addis Ababa in the 2015/2016 academic session, totaling 720 . However, the researcher used $10 \%$ as the sample size of the total population i.e720.For the purpose of this study to reliable; the researcher selected 72 students using random sampling technique.

In addition to this, research required $12 \mathrm{EFL}$ Teachers as purposive sampling because they are easily manageable. Therefore the total subjects of the study were 84 . For the purpose of this study, the major research tool used to gather data was observation. The second tool is semi structured interviews for teachers. The third one was questionnaires administered to teachers and students who were selected randomly from grade nine students.

During the observation sessions, the researcher had observed how students are learning writing skills, the kind of activities/tasks being used, how students were supporting each other so as to alleviate their personal status and the factors that impeded the writing 
instruction. Also the teachers' teaching techniques, the way they present and manage the writing tasks and the nature of the activities were observed.

However, Semi structured interview with five EFL teachers. One of the major reasons is that it is one of the widely used research tools in qualitative (descriptive) research study to assess people's experiences, their inner perceptions, attitudes, and feelings of reality.

The sample of the study was given three items questionnaire. The first questionnaire dealt with the students and teachers personal information, the second one with students' writing practices and strategies of writing and the last one dealt with the teachers' perception, practice and techniques of the teaching writing skills. Additionally, 10 closed ended questionnaires were distributed for students and 13 closed ended questionnaires for teachers to gather their perception as well as 14 closed ended questionnaires for teachers to gather their practice of constructivist approach and one open ended questionnaire about the challenges that affect them in teaching writing skill.

After the data had been collected the responses to the questionnaire part and information obtained through observation and recordings were counted and tallied then, descriptive statistics were employed in analyzing the quantitative data while content analysis was applied in analyzing the qualitative data. The collected raw data was analyzed using mean score for quantitative method of data analysis and qualitatively interpretation to ensure the reliability and validity of the collected data.

\section{DATA ANALYSIS AND RESULTS \\ Back Ground Information of the Respondents Back Ground Information of Students}

Table-1: Sex and first language of Student Respondents

\begin{tabular}{|l|l|l|l|l|}
\hline No & Variables & Characteristics & \multicolumn{2}{|c|}{$\mathbf{( N = 7 2}$} \\
\hline & & & $\mathrm{N}$ & $\%$ \\
\hline \multirow{2}{*}{$\mathrm{A}$} & \multirow{2}{*}{ Sex } & $\mathrm{M}$ & 32 & 44 \\
\cline { 3 - 5 } & & $\mathrm{F}$ & 40 & 56 \\
\hline \multirow{2}{*}{$\mathrm{B}$} & \multirow{2}{*}{ Language } & Amharic & 42 & 58 \\
\cline { 3 - 5 } & & Afaan oromo & 20 & 28 \\
\cline { 3 - 5 } & & Others & 10 & 14 \\
\hline
\end{tabular}

This table shows the respondents of the students in grade nine who are matured enough to be instructed by problem solving or active learning method in a constructivist writing classroom.

\section{Back Ground Information of Teachers}

Table-2: Teachers' Sex, Age, Experience in Teaching, and Qualification

\begin{tabular}{|l|l|l|l|l|}
\hline No & Variables & Characteristics & \multicolumn{2}{|l|}{$(\mathbf{N}=12)$} \\
\hline & & & $\mathrm{N}$ & $\%$ \\
\hline 1 & \multirow{2}{*}{ SEX } & $\mathrm{M}$ & 11 & 92 \\
\cline { 3 - 5 } & & $\mathrm{F}$ & 1 & 8 \\
\hline 2 & \multirow{2}{*}{ Teachers' experience in teaching } & $1-5$ & 2 & 17 \\
\cline { 3 - 5 } & & $6-10$ & 7 & 58 \\
\cline { 3 - 5 } & & Above 11 & 3 & 25 \\
\hline 3 & Average number of students per class & & 50 & \\
\hline 4 & Qualification & Degree holders & 12 & 100 \\
\hline
\end{tabular}

Table-2 shows that twelve teachers were included in the study with regard to their sex $(92 \%)$ of the teachers were males, while the remaining $(8 \%)$ was female. Compared with male teachers, the number of female teacher in Beseka Secondary School was few. As to work experience in teaching of the respondents $2(17 \%)$ of the teachers were $1-5$ years whereas 7 $(66.7 \%)$ of them were 6-10 years while the remaining $3(25 \%)$ were above 11 .

With the respect to the educational background or qualification, $100 \%$ of the English teachers in the school were first-degree holders in academic subject respectively. As to their teaching load, 100\% had 18 teaching load per week respectively. Here it was observed that majority of the teachers had the teaching load ranging 18 periods per a week, which can overburden them to facilitate constructivist techniques in their respecting schools.

Research Question 1: To what extent an EFL teacher's practice constructivist approach in writing classroom?

Table-3: Teachers' response about the nature of writing

\begin{tabular}{|c|c|c|c|c|c|c|c|c|c|c|c|c|c|c|c|c|}
\hline \multirow[t]{2}{*}{ No } & & \multicolumn{3}{|c|}{$\begin{array}{l}\text { Strongly } \\
\text { agree }\end{array}$} & \multicolumn{3}{|c|}{ agree } & \multicolumn{3}{|c|}{ Undecided } & \multicolumn{3}{|c|}{ Disagree } & \multicolumn{3}{|c|}{$\begin{array}{l}\text { strongly } \\
\text { disagree }\end{array}$} \\
\hline & & $\mathbf{F}$ & $\%$ & mean & $\mathbf{F}$ & $\%$ & mean & $\mathbf{F}$ & $\%$ & Mean & $\mathbf{F}$ & $\%$ & mean & $\mathbf{F}$ & $\%$ & Mean \\
\hline 1 & $\begin{array}{l}\text { Writing is more } \\
\text { inborn than learned }\end{array}$ & & & & 2 & 16.7 & 0.7 & & & & 4 & 33.3 & 0.67 & 6 & 50 & 0.5 \\
\hline
\end{tabular}


When the researcher examine the perception of teachers about the nature of writing, their responses showed that $6(50 \%)$ of the respondents and 4(33.3\%) had the perception that writing was not inborn but learned through practice and explicit teaching but $2(16.7 \%)$ of the respondents agree. So the mean value of disagree is greater than agree that means writing is a learned skills.

Table-4: Teachers' response towards regular practice of writing

\begin{tabular}{|c|c|c|c|c|c|c|c|c|c|c|c|c|c|c|}
\hline \multirow[t]{2}{*}{ No } & & \multicolumn{3}{|c|}{ Strongly agree } & \multicolumn{3}{|c|}{ agree } & \multicolumn{3}{|c|}{ Undecided } & \multicolumn{2}{|c|}{ Disagree } & \multicolumn{2}{|c|}{ Strongly } \\
\hline & & $\mathbf{F}$ & $\%$ & Mean & $\mathbf{F}$ & $\%$ & Mean & $\mathbf{F}$ & $\%$ & Mean & $\mathbf{F}$ & $\%$ & $\mathbf{F}$ & $\%$ \\
\hline 2 & Writing require regular practice & 7 & 58.3 & 2.9 & 5 & 41.7 & 1.7 & & & & & & & \\
\hline
\end{tabular}

According to above table, the perception of teachers about the practice of writing, showed that $7(58 \%)$ of the respondents, strongly agree and $5(42 \%)$ had the perception that writing can be learned through regular practice and explicit teaching therefore the researcher agree with them. Teachers should motivate students to practice the skill meaningfully and repeatedly and facilitate situations in which they can get comments on their writing either from their instructor by Practicing writing continuously especially by integrating it with other language skills as one of the remedial solutions to implement the process approach.

Table-5: Response of teachers to make students write in English

\begin{tabular}{|c|c|c|c|c|c|c|c|c|c|c|c|c|c|c|c|c|}
\hline \multirow[t]{2}{*}{ No } & & \multicolumn{3}{|c|}{$\begin{array}{l}\text { Strongly } \\
\text { agree }\end{array}$} & \multicolumn{3}{|c|}{ Agree } & \multicolumn{3}{|c|}{ Undecided } & \multicolumn{3}{|c|}{ Disagree } & \multicolumn{3}{|c|}{$\begin{array}{l}\text { Strongly } \\
\text { disagree }\end{array}$} \\
\hline & & $\mathbf{F}$ & $\%$ & $\mathbf{M}$ & $\mathbf{F}$ & $\%$ & Mean & $\mathbf{F}$ & $\%$ & M & $\mathbf{F}$ & $\%$ & $\mathbf{M}$ & $\mathbf{F}$ & $\%$ & $\mathbf{M}$ \\
\hline 4 & $\begin{array}{l}\text { Students should be made to } \\
\text { write in English before they } \\
\text { master the English grammar }\end{array}$ & & & & 4 & 33.3 & 1.33 & & & & 6 & 50 & 1 & 2 & 16 & 0.2 \\
\hline 5 & $\begin{array}{l}\text { In the process of writing at } \\
\text { high school level, more } \\
\text { focuses should be to grammar } \\
\text { and vocabulary }\end{array}$ & 1 & 8.3 & 0.4 & 3 & 25 & 1 & & & & 5 & 41.7 & 0.8 & 3 & 25 & 0.3 \\
\hline
\end{tabular}

As the above table shows, the perception of teachers responses showed that $4(33.3 \%)$ of the respondents agree that in the process of teaching writing at high school, Students should be made to write in English before they master the English grammar. Process writing experts like Zamel [12], contrarily, suggest that even beginner writers who have difficulty to express themselves in grammatically correct sentences can learn writing through continuous and meaningful practices where as $6(50 \%)$ disagree and $2(16.7 \%)$ strongly disagree that grammar is vital for students to write.

As to question 5, the teachers response showed that $1(8.3 \%)$ of the respondents strongly agree and $3(25 \%$ agree that in the process of teaching writing at high school, more focus should be given to grammar and vocabulary whereas $5(41.7 \%)$ disagree and $3(25 \%)$ strongly disagree that other aspect of writing such genre, purpose and audience should precede grammar and vocabulary. Therefore the researcher can conclude that most of us have grammar problem so we cannot write good paragraphs or essays.

If we have good command of grammar, we can write correct sentences or paragraphs, but if our grammar is poor, no one can understand our ideas. Generally when learners are provided with contextualized grammar awareness activities in conjunction with writing activities, it is possible to make them good writers who can produce well developed written texts which are made up of intelligible grammar.

Research Question 2: What are teachers' perceptions towards constructivist approach while teaching writing?

Table-6: Teachers response towards constructivist approach in writing classroom

\begin{tabular}{|c|c|c|c|c|c|c|c|c|c|c|c|c|c|c|c|c|}
\hline \multirow[t]{2}{*}{ No } & & \multicolumn{3}{|c|}{$\begin{array}{l}\text { Strongly } \\
\text { agree }\end{array}$} & \multicolumn{3}{|c|}{ agree } & \multicolumn{3}{|c|}{ Undecided } & \multicolumn{3}{|c|}{ Disagree } & \multicolumn{3}{|c|}{$\begin{array}{l}\text { Strongly } \\
\text { disagree }\end{array}$} \\
\hline & & $\mathbf{F}$ & $\%$ & $\mathbf{M}$ & $\mathbf{F}$ & $\%$ & $\mathbf{M}$ & $\mathbf{F}$ & $\%$ & $\mathbf{M}$ & $\mathbf{F}$ & $\%$ & $\mathbf{M}$ & $\mathbf{F}$ & $\%$ & $\mathbf{M}$ \\
\hline 7 & $\begin{array}{l}\text { Constructivist approach is } \\
\text { appropriate for teaching writing } \\
\text { skill. }\end{array}$ & 6 & 50 & 2.5 & 5 & 41.7 & 1.7 & 1 & 8.3 & 0.25 & & & & & & \\
\hline 8 & $\begin{array}{l}\text { Interactive and model-reflective } \\
\text { writing techniques enhance } \\
\text { students motivation during } \\
\text { writing }\end{array}$ & 6 & 50 & 2.5 & 6 & 50 & 2.5 & & & & & & & & & \\
\hline
\end{tabular}


As the above table shows, the perception of teachers response showed that $6(50 \%)$ of the respondents strongly agree and $5(41.7 \%)$ agree that using constructivist techniques and strategies are vital for teaching writing skill to improve students writing ability. Additionally the perception of teachers responses about question 8 , showed that $6(50 \%)$ of the respondents strongly agree and $6(50 \%)$ agree that interactive -reflective model techniques enhance students motivation during writing.

Table-7: Response of teachers towards students' pair and written feedback

\begin{tabular}{|c|c|c|c|c|c|c|c|c|c|c|c|c|c|c|c|c|}
\hline \multirow[t]{2}{*}{ No } & & \multicolumn{3}{|c|}{$\begin{array}{l}\text { Strongly } \\
\text { agree }\end{array}$} & \multicolumn{3}{|c|}{ agree } & \multicolumn{3}{|c|}{ Undecided } & \multicolumn{3}{|c|}{ Disagree } & \multicolumn{3}{|c|}{$\begin{array}{l}\text { strongly } \\
\text { disagree }\end{array}$} \\
\hline & & $\mathbf{F}$ & $\%$ & $\mathbf{M}$ & $\mathbf{F}$ & $\%$ & $\mathbf{M}$ & $\mathbf{F}$ & $\%$ & $\mathbf{M}$ & $\mathbf{F}$ & $\%$ & $\mathbf{M}$ & $\mathbf{F}$ & $\%$ & $\mathbf{M}$ \\
\hline 9 & $\begin{array}{l}\text { Making students correct each } \\
\text { others' written tasks is helpful } \\
\text { for improving their skill }\end{array}$ & 6 & 50 & 2.5 & 6 & 50 & 2.5 & & & & & & & & & \\
\hline 10 & $\begin{array}{l}\text { Teachers' written feedback can } \\
\text { help learners improves their } \\
\text { writing skills }\end{array}$ & 7 & 58.3 & 2.9 & 3 & 25 & 1 & & & & 2 & 16.7 & 0.3 & 7 & 58.3 & 2.9 \\
\hline
\end{tabular}

As the above table shows, the perception of teachers about the students pair corrections of written task, their responses showed that $12(100 \%)$. agree that effective peer response is important way of helping novice writes to understand how readers see their work, assist learners by providing opportunities for practice, for revision and writing in response to their peer feedback. Generally, properly addressed feedback either by teacher or by peer-group will motivate and facilitate the improvement of their writing skills.

As the above table shows, the perception of teachers about the written feedback, their responses showed that $7(58.3 \%)$ of the respondents strongly agree and $3(25 \%$ agree that teachers written feedback can help learners improve their writing skill, whereas $2(16.7 \%)$ disagree that due to various factors such class size, duration of lesson i.e. within 45 minutes per lesson, it is difficult to give written feedback regularly. In process-based classrooms, feedback is seen as an important developmental tool moving learners through multiple drafts towards the capability for effective self expression [13, Keh [14] also points out the same idea that feedback is a fundamental element of process approach to writing. It is possible to say that feedback is an input from the reader to a writer with the effect of providing information to the writer for revision.

Table-8:Teachers'response towards collaborative writing

\begin{tabular}{|c|c|c|c|c|c|c|c|c|c|c|c|c|c|c|c|c|}
\hline \multirow[t]{2}{*}{ No } & & \multicolumn{3}{|c|}{$\begin{array}{l}\text { Strongly } \\
\text { agree }\end{array}$} & \multicolumn{3}{|c|}{ agree } & \multicolumn{3}{|c|}{ Undecided } & \multicolumn{3}{|c|}{ Disagree } & \multicolumn{3}{|c|}{$\begin{array}{l}\text { strongly } \\
\text { disagree }\end{array}$} \\
\hline & & $\mathbf{F}$ & $\%$ & $\mathbf{M}$ & $\mathbf{F}$ & $\%$ & $\mathbf{M}$ & $\mathbf{F}$ & $\%$ & $\mathbf{M}$ & $\mathbf{F}$ & $\%$ & $\mathbf{M}$ & $\mathbf{F}$ & $\%$ & $\mathbf{M}$ \\
\hline 11 & $\begin{array}{l}\text { Teachers and students should } \\
\text { work together to produce their } \\
\text { texts. }\end{array}$ & & & & 4 & 33.3 & 1.3 & 2 & 16.7 & 0.5 & 6 & 50 & 1 & & & \\
\hline
\end{tabular}

As the above table shows, the perception of teachers about the collaborative writing, their responses showed that $4(33.3 \%)$ of the respondents agree that teachers and students should work together to produce their texts but $6(50 \%)$ disagree that they should not work together. The researcher concluded that in collaborative writing, teachers should play a fundamental to guide students work together to write produce their texts

Table-9: Teachers' response about writing techniques and strategies

\begin{tabular}{|c|c|c|c|c|c|c|c|c|c|c|c|c|c|c|c|c|}
\hline \multirow[t]{2}{*}{ No } & & \multicolumn{3}{|c|}{$\begin{array}{l}\text { Strongly } \\
\text { agree }\end{array}$} & \multicolumn{3}{|c|}{ agree } & \multicolumn{3}{|c|}{ Undecided } & \multicolumn{3}{|c|}{ Disagree } & \multicolumn{3}{|c|}{$\begin{array}{l}\text { strongly } \\
\text { disagree }\end{array}$} \\
\hline & & $\mathbf{F}$ & $\%$ & $\mathbf{M}$ & $\mathbf{F}$ & $\%$ & $\mathbf{M}$ & $\mathbf{F}$ & $\%$ & $\mathbf{M}$ & $\mathbf{F}$ & $\%$ & $\mathbf{M}$ & $\mathbf{F}$ & $\%$ & $\mathbf{M}$ \\
\hline 12 & $\begin{array}{l}\text { In teaching learning process } \\
\text { of writing, writing strategies } \\
\text { should be taught explicitly }\end{array}$ & 8 & 66.7 & 3.3 & 4 & 33.3 & 1.3 & & & & & & & & & \\
\hline 13 & $\begin{array}{l}\text { In teaching process of writing, } \\
\text { making students' brainstorm } \\
\text { for ideas, write a first draft } \\
\text { and edit is a waste of time. }\end{array}$ & & & & 3 & 25 & 1 & & & & 6 & 50 & 1 & 3 & 25 & 0.25 \\
\hline
\end{tabular}


According to above table, the perception of teachers' response about the writing strategies, showed that $8(66.7 \%)$ of the respondents strongly agree and $4(33.3 \%)$ agree that writing strategies should be taught explicitly to motivate and encourage students to actively engaged in teaching learning process. on the other hand, the perception of teachers about brainstorm in writing class, showed that $3(25 \%)$ of the respondents agree that making students' brainstorm for ideas, write a first draft and edit is a waste of time therefore it is not necessary but $6(50 \%)$ disagree and $3(25 \%)$ strongly disagree that they should brainstorm for ideas, write, and edit their work together. Generally writing strategies should be taught explicitly to help students practice them in order to compose their texts accordingly.

Teachers' response towards implementing constructivists' principles in writing classroom

Table-10: Response of teachers towards engaging learners actively in writing classroom

\begin{tabular}{|c|c|c|c|c|c|c|c|c|c|c|c|c|c|c|c|c|}
\hline \multirow[t]{2}{*}{ No } & & \multicolumn{3}{|c|}{ Always } & \multicolumn{3}{|c|}{ Usually } & \multicolumn{3}{|c|}{ Sometimes } & \multicolumn{3}{|c|}{ Rarely } & \multicolumn{3}{|c|}{ Never } \\
\hline & & $\mathbf{F}$ & $\%$ & $\mathbf{M}$ & $\mathbf{F}$ & $\%$ & $\mathbf{M}$ & $\mathbf{F}$ & $\%$ & $\mathbf{M}$ & $\mathbf{F}$ & $\%$ & $\mathbf{M}$ & $\mathbf{F}$ & $\%$ & $\mathbf{M}$ \\
\hline 1 & $\begin{array}{l}\text { Actively engage learners' } \\
\text { in writing classroom. }\end{array}$ & 5 & 41.7 & 0.83 & 4 & 33.3 & 1.3 & 3 & 25 & 0.75 & & & & & & \\
\hline 2 & $\begin{array}{l}\text { Demonstrate empathy and } \\
\text { respect students to ask, } \\
\text { share, and reflect on their } \\
\text { written work. }\end{array}$ & 4 & 33.3 & 1.7 & 5 & 41.7 & 1.7 & 3 & 25 & 0.75 & & & & & & \\
\hline
\end{tabular}

As the above table shows, the practice of teachers about actively engaging learners in writing class showed that $5(41.7 \%)$ of the respondents, $4(33.3 \%)$ Always and $3(25 \%)$ usually during teaching writing, hence it is better for students to participate actively to write effectively and accordingly in order to master their writing and the practice of teachers about demonstrating empathy and respect for learners in writing class, their responses showed that $4(33.3 \%)$ of the respondents, Always 5(41.7\%) usually and 3(25\%) sometimes to make them ask, share and reflect on their written works during teaching writing, therefore, it is better for students to participate actively without frustration to write freely.

Table-11: Response of teachers towards encouraging learners.

\begin{tabular}{|c|c|c|c|c|c|c|c|c|c|c|c|c|c|c|c|c|}
\hline \multirow[t]{2}{*}{ No } & & \multicolumn{3}{|c|}{ Always } & \multicolumn{3}{|c|}{ Usually } & \multicolumn{3}{|c|}{ Sometimes } & \multicolumn{3}{|c|}{ Rarely } & \multicolumn{3}{|c|}{ Never } \\
\hline & & $\mathbf{F}$ & $\%$ & M & $\mathbf{F}$ & $\%$ & $\mathbf{M}$ & $\mathbf{F}$ & $\%$ & M & $\mathbf{F}$ & $\%$ & M & $\mathbf{F}$ & $\%$ & M \\
\hline 3 & $\begin{array}{l}\text { Encourage students to } \\
\text { practice writing using } \\
\text { the writing strategies. }\end{array}$ & 5 & 41.7 & 2.08 & 5 & 41.7 & 1.7 & 1 & 8.3 & 0.25 & 1 & 8.3 & 0.17 & & & \\
\hline 4 & $\begin{array}{l}\text { Create conducive } \\
\text { environment for all } \\
\text { students to learn, } \\
\text { interact and involve in } \\
\text { writing activity. }\end{array}$ & 5 & 41.7 & 2.08 & 7 & 58.3 & 2.3 & & & & & & & & & \\
\hline
\end{tabular}

As the above table shows, the practice of teachers about encouraging learners to practice writing strategies, their responses showed that $5(41.7 \%)$ of the respondents, Always 5(41.7\%) usually and 1(8.3\%) sometimes and rarely respectively to make them practice writing strategies. As question 4 , the practice of teachers about Creating conducive environment for all students to learn, interact and involve them in writing activity, their responses showed that 5(41.7\%) of the respondents, Always and 5(41.7\%) usually.

Table-12: Response of teachers' role in writing classroom

\begin{tabular}{|c|c|c|c|c|c|c|c|c|c|c|c|c|c|c|c|c|}
\hline \multirow[t]{2}{*}{ No } & & \multicolumn{3}{|c|}{ Always } & \multicolumn{3}{|c|}{ Usually } & \multicolumn{3}{|c|}{ Sometimes } & \multicolumn{3}{|c|}{ Rarely } & \multicolumn{3}{|c|}{ Never } \\
\hline & & $\mathbf{F}$ & $\%$ & M & $\mathbf{F}$ & $\%$ & $\mathbf{M}$ & $\mathbf{F}$ & $\%$ & M & $\mathbf{F}$ & $\%$ & $\mathbf{M}$ & $\mathbf{F}$ & $\%$ & M \\
\hline 5 & $\begin{array}{l}\text { Motivate students to play a } \\
\text { central role in what they } \\
\text { write, how they write it and } \\
\text { why they write. }\end{array}$ & 4 & 33.3 & 1.7 & 3 & 25 & 1 & 5 & 41.7 & 1.3 & & & & & & \\
\hline 6 & $\begin{array}{l}\text { Teachers serve as guide, } \\
\text { coaches, tutors and facilitator } \\
\text { in writing session }\end{array}$ & 3 & 25 & 1.25 & 6 & 50 & 1.7 & 3 & 25 & 0.8 & & & & & & \\
\hline
\end{tabular}


As the above table shows, the practice of teachers about motivating learners to play a crucial role in not only how to write but also why to write, their responses showed that $4(33.3 \%)$ of the respondents, Always 3(25\%) usually and 5(41.7 \%) sometimes. And responses of teachers role in writing classroom showed that $3(25 \%)$ of the respondents, Always $6(50 \%)$ usually and $3(25 \%)$ sometimes. The researcher can conclude that teacher should a crucial role to model all aspects of writing process many times so that students become familiar with each stage that will enable them to participate with understanding and confidence.

Table-13: Response of teachers towards giving opportunities for students

\begin{tabular}{|l|l|l|l|l|l|l|l|l|l|l|l|l|l|l|l|l|}
\hline No & \multicolumn{3}{|l|}{ Always } & \multicolumn{3}{l|}{ Usually } & \multicolumn{3}{l|}{ Sometimes } & \multicolumn{2}{l|}{ Rarely } & \multicolumn{2}{|l|}{ Never } \\
\hline 9 & $\begin{array}{l}\text { Provide opportunities for students } \\
\text { to discuss about the written material } \\
\text { interactively and Constructively. }\end{array}$ & 1 & 8.3 & 0.4 & 8 & 67 & 2.7 & 3 & 25 & 0.8 & & & & & \\
\hline 10 & $\begin{array}{l}\text { The learners previous knowledge } \\
\text { and needs, are considered in writing } \\
\text { process }\end{array}$ & 3 & 25 & 1.3 & 6 & 50 & 1.7 & 3 & 25 & 0.8 & & & & & & \\
\hline
\end{tabular}

As the above table shows, the practice of teachers to provide opportunities for students to discuss about the written material interactively and constructively to learn actively, their responses showed that $1(8.3 \%)$ of the respondents always, $8(66.7 \%)$ usually and $3(25 \%)$ sometimes to make students learn, and discuss about written material interactively. As it is clearly illustrated from the table above, writing skills can be developed when the learners' interests are acknowledged and when they are given frequent opportunities to actually practice writing [15]. Because one of the main goals of EFL students is to learn to produce a well-thought-out piece of writing, a specific writing program must be in place in order to meet the needs of these learners.

And the practice of teachers to provide opportunities for students to discuss about the written material interactively and constructively to learn actively, their responses showed that $1(8.3 \%)$ of the respondents always, 8(66.7\%) usually and 3(25\%) sometimes to make students learn, and discuss about written material interactively. Activating prior knowledge is one method in which teachers can assist EFL students before they even begin writing. Making sure students have the opportunity to think about what they already know before the task begins to help them incorporate new information into existing structures of knowledge which activates long-term memory [16]. Several strategies can be used to accomplish this including graphic organizers, cooperative learning, read-aloud, and group discussions. Graphic organizers can be used as visual tools for students to write or draw what they already know about a subject, for example in the genre of informational or persuasive writing.

Table-14: Response of teachers practice towards Constructivist techniques

\begin{tabular}{|c|c|c|c|c|c|c|c|c|c|c|c|c|c|c|c|c|}
\hline \multirow[t]{2}{*}{ No } & & \multicolumn{3}{|c|}{ Always } & \multicolumn{3}{|c|}{ Usually } & \multicolumn{3}{|c|}{ Sometimes } & \multicolumn{3}{|c|}{ Rarely } & \multicolumn{3}{|c|}{ Never } \\
\hline & & $\mathbf{F}$ & $\%$ & $\mathbf{M}$ & $\mathbf{F}$ & $\%$ & M & $\mathbf{F}$ & $\%$ & M & $\mathbf{F}$ & $\%$ & $\mathbf{M}$ & $\mathbf{F}$ & $\%$ & $\mathbf{M}$ \\
\hline 11 & $\begin{array}{l}\text { Apply Constructivist techniques to } \\
\text { make students write not only in } \\
\text { group but also independently in a } \\
\text { writing classroom }\end{array}$ & 5 & 42 & 2.1 & 3 & 25 & 1 & 3 & 25 & 0.5 & 1 & 8 & 0.2 & & & \\
\hline 12 & $\begin{array}{l}\text { Taught students via cooperative } \\
\text { learning to find ideas about the topic, } \\
\text { organize themselves to generate } \\
\text { further ideas about writing task. }\end{array}$ & 2 & 17 & 0.8 & 8 & 67 & 2.7 & & & & 2 & 17 & 0.3 & & & \\
\hline
\end{tabular}

According to above table, the teachers' responses showed that $5(41.7 \%)$ of the respondents always, $3(25 \%)$ usually, $3(25 \%)$ sometimes and $1(8.3 \%)$ rarely to apply Constructivist techniques to make students write not only in group but also independently in a writing classroom and responses about cooperative learning showed that $2(16.7 \%)$ of the respondents always, $8(66 \%)$ usually, and 2(16.7\%) rarely to teach students to find ideas about the given topics, and organize themselves in cooperative learning methods. 
Table-15: Perception about group work learning in writing class

\begin{tabular}{|c|c|c|c|c|c|}
\hline \multirow[t]{2}{*}{ No } & & \multicolumn{2}{|l|}{ Yes } & \multicolumn{2}{|c|}{ No } \\
\hline & & Frequency & $\%$ & $\mathbf{F}$ & $\%$ \\
\hline 1 & $\begin{array}{l}\text { Group/Pair learning is an important technique of learning writing in order } \\
\text { to improve our writing abilities. }\end{array}$ & 52 & 72.3 & 20 & 27.7 \\
\hline
\end{tabular}

The purpose of this questionnaire was to see the perceptions of students about group/pair learning in their Writing classes. According to the constructionists' point of view, writing is a social act which requires the co-operation of different individuals who have relationship with the subject matter under discussion. When their view is further examined, pair/group learning has a strong contribution to any writing instruction paradigm. Having this view in mind, the respondents were asked whether group/pair work had its own benefit when they learned Writing Skills.

As it can be seen from the table, 52(72.3\%) of the respondents yes, that group/pair work was an important technique that had significant role in improving their skills. The other $20(27.7 \%)$ of the respondents, in contrast, disagreed to the statement. Their disagreement to the above statement might be due to their understanding that writing is a skill that can be learnt either through the individual effort of the learner or the instruction that they received from the instructor.

\section{REFERENCE}

1. Zeichner, K. M., \& Liston, D. P. (1996). Historical roots of reflective teaching. Reflective teaching: An introduction, 8-22.

2. Holzer, H. J. (1994). Black employment problems: New evidence, old questions. Journal of Policy Analysis and Management, 13(4), 699-722.

3. Wallace, M. J., \& Bau, T. H. (1991). Training foreign language teachers: A reflective approach. Cambridge University Press.

4. McDonough, S. (1990). What's the use of research?.

5. Burns, D. D. (1999). The feeling good handbook, Rev. Plume/Penguin Books.

6. Perin, L., Giuliani, S., Jin, D., Sedrakyan, S., Carraro, G., Habibian, R., ... \& De Filippo, R. E. (2007). Renal differentiation of amniotic fluid stem cells. Cell proliferation, 40(6), 936-948.
7. Krashen, S. D. (1987). Applications of psycholinguistic research to the classroom. Methodology in TESOL, 33-44.

8. Nunan, D. (1999). Language Teaching Methodology: London: Prentice Hall.

9. Alamirew, G. (2005). A Study on the Perception of Writing, Writing Instruction and Studentse Writing Performance. Unpublished PhD Dissertation. Addis Ababa: Addis Ababa University.

10. Adaye, Y. (1996). Teaching Writing as a Process at First year level at Addis Ababa University. Unpublished Master" s Thesis, Addis Ababa University, School of Graduate Studies, Addis Ababa.

11. Geremew, L. (1999). A Study of the Requirements in Writing for Academic Purposes At Addis Ababa University: Four Departments in Focus. Unpublished PhD Dissertation, Addis Ababa University.

12. Zamel, V. (1983). The composing processes of advanced ESL students: Six case studies. TESOL quarterly, 17(2), 165-188.

13. Hyland, K., \& Hyland, F. (2006). Interpersonal aspects of response: Constructing and interpreting teacher written feedback. Feedback in second language writing: Contexts and issues, 206-224.

14. Keh, C. L. (1990). Feedback in the writing process: A model and methods for implementation.

15. Ismail, A. M., Heuer, S., Thomson, M. J., \& Wissuwa, M. (2007). Genetic and genomic approaches to develop rice germplasm for problem soils. Plant molecular biology, 65(4), 547-570.

16. Clausen, D. (2017). Empowering English Language Learners in Postsecondary Classrooms An Inquiry into Best Practices. Journal of Alternative Perspectives in the Social Sciences, 8(4), 452-473. 